\title{
Research of Chemical Pre-treatment Created by Sol-gel Process on the Polished Surface of Aluminium Substrate
}

Jaroslava Svobodova, Pavel Kraus, Jaromir Cais, Radek Lattner

Faculty of Production Technology and Management, J. E. Purkyne University in Usti nad Labem. Pasteurova 7, 40096 Usti nad Labem. Czech Republic. E-mail: svobodova@fvtm.ujep.cz, kraus@fvtm.ujep.cz, cais@fvtm.ujep.cz, lattnerr@fvtm.ujep.cz

This paper reports the preparation and characterization of thin transparent nanolayers with phase composition $\mathrm{ZrF}_{4}$ and different modification of $\mathrm{SiO}_{2}$ with special focus on the affecting the surface roughness of the material and the way of exclusion of the thin nanolayer on the surface of the polished aluminium material. The thin nanolayer was prepared by the sol-gel method. The final treatment based on PTFE was applied on the surface of some samples. This treatment is suitable for the increasing of the wear resistance. The films were characterized with help of SEM microscopy and EDS analysis. The surface roughness was measured with classical surface roughness tester. There was published results on this theme but not on the polished surface of the aluminium material. The results from the experiment shows on the problems with application of these nanolayers because there were found a cracks on the surface of the material and deformations of the layer after application of two nanoproduts and PTFE final layer. The surface layer formation is discussed.

Keywords: sol-gel technology, nanolayers, aluminium alloys, surface roughness, SEM

\section{References}

[1] BALGUDE, D., SABNIS, A., SOL-GEL SCI TECHNOL. (2012). Sol-gel derived hybrid coatings as and environment friendly surface treatment for corrosion protection of metals and their alloys, Springer, Vol. 64, pp. 124134, DOI 10.1007/S10971-012-2838-z.

[2] SVOBODOVA, J. (2014). SEM and EDS Analysis Used in Evaluation of Chemical Pre-treatment Based on Nanotechnology. Manufacturing Technology, Journal for Science, Research and Production, Vol. 14, No. 3, ISSN 1213-2489.

[3] CHOU, T. P., CHANDRASEKARAN, C., LIMMER, S., NGUYEN, C., CAO, G. Z. (2002). Organic-inorganic sol-gel coating for corrosion protection of stainless steel, Journal of Materials Science Letters, Vol. 21, p. 251255, Print ISSN: 0261-8028; Online ISSN: 1573-4811.

[4] NOVOTNA, P., KRYSA, J., MAIXNER, J., KLUSON, P., NOVAK, P. (2010). Photocatalytic activity of sol-gel $\mathrm{TiO} 2$ thin films deposited on soda lime glass and soda lime glass precoated with a SiO2 layer, Surface \& Coatings Technology, Vol. 204, p. 2570-2575, ISSN 0257-897, 2 DOI:10.1016/j.surfcoat.2010.01.043.

[5] SVOBODOVA, J. (2015). Evaluation of New Type of Chemical Pre-treatment Applied on Low-carbon Steel Substrate Using SEM and EDS Analysis, Engineering for Rural Development, 14th International Scientific Conference, ISSN 1691-5976 (dostupné na http://www.tf.llu.lv/conference/proceedings2015).

[6] VOEVODIN, A. A., SHTANSKY, D. V., LEVASHOV, E., A., MOORE, J. J. (2004). Nanostructured Thin Films and Nanodispersion Strengthened Coatings, Springer - Nato Science Series II, Vol. 155, ISBN 1-4020-2221-2.

[7] CAVAlEIRO, A., HOSSON, J. T. (2006). Nanostructured Coatings - Nanostructure Science and Technology, Springer, p. 648, ISBN 0-387-25642-3.

[8] SVOBODOVÁ, J., KRAUS, P. (2015). Hodnocení drsnosti a morfologie povrchu hliníkového plechu po aplikaci chemických předúprav na bázi nanotechnologií, Strojírenská technologie, ročník XX, číslo 2, s. 103-109, ISSN 1211-4162. 